\title{
Times of CONTINUITY AND DeVelopMENT. Visions of The Future aMong Agro-PAstoral Children AND Young People in SOUTHern ETHIOPIA
}

\author{
Sabrina MAURUS*
}

\begin{abstract}
This article explores how children and young people from agro-pastoral societies in southern Ethiopia imagine their future. Children and young people who have not been going to school, as well as students in rural and urban areas, imagine their future differently. Their visions of the future can be located on a continuum between a future life as agropastoralists on the one end, and life in town with a job as an employee on the other. Where a person's vision is located on this continuum depends on the influences he or she has experienced from school and town life. My analysis shows how, through the influence of schooling, young people's concept of time shifts from a cyclical one, concentrated on the reproduction of the social world, towards a linear one, focused on personal and "national" development.
\end{abstract}

Keywords - Pastoralism; childhood; youth; students; education; school; future; time; Ethiopia

Résumé - Temps continu et développement. Visions du futur chez les enfants et les jeunes agropasteurs du Sud-éthiopien. Cet article explore la manière dont des enfants et des jeunes, originaires de sociétés agro-pastorales du sud de l'Ethiopie, imaginent leur avenir. Les enfants et les jeunes qui ne sont pas allés à l'école, comme les étudiants de milieu urbain et rural, l'imaginent différemment. Leur représentation de l'avenir se situe le long d'un continuum entre la vie agro-pastorale d'un côté et la vie en ville de l'autre, avec un poste d'employé à la clé. La place de l'imagination d'une personne donnée dépend de l'expérience scolaire et urbaine préalables. Mon analyse montre qu'à travers l'influence de l'école, la perception du temps par les élèves passe d'une conception cyclique, focalisée sur la reproduction du monde social, à une conception linéaire, focalisée sur le développement à la fois personnel et « national».

Mots-clés - Pastoralisme ; enfance ; jeunesse ; étudiants ; éducation ; école ; future ; temps ; Ethiopie

Resumen - Tiempo continuo y desarrollo. Imaginaciones del futuro entre los niños y los jóvenes agropastores del Sur de Etiopia. Este artículo explora la forma por la cual los niños y los jóvenes originarios de sociedades agro-pastorales del sur de Etiopía, imaginan su porvenir. Los niños y los jóvenes que no fueron a la escuela, como los estudiantes del medio urbano y rural lo imaginan de forma diferente. Su representación del porvenir se sitúa a lo largo de un continuum entre la vida agro-pastoral, por un lado, y la vida en la ciudad, por el otro, con una plaza de empleado perene. El lugar de la imaginación de una persona determinada depende de la previa experiencia escolar y urbana. Mi análisis muestra que a través de la

\footnotetext{
* Sabrina Maurus, PhD candidate at Bayreuth International Graduate School of African Studies (BIGSAS), University of Bayreuth, sabrina.maurus@uni-bayreuth.de
} 
influencia de la escuela, la percepción del tiempo para los estudiantes pasa de una concepción cíclica, focalizada sobre la reproducción del mundo social a una concepción lineal, focalizada en el desarrollo tanto personal como "nacional".

Palabras clave - Pastoralismo; infancia; juventud; estudiantes; educación; escuela; futuro; tiempo; Etiopia

\section{INTRODUCTION}

CHILDREN AND YOUNG PEOPLE IN AFRICA experience a different socialization depending on whether or not they go to school. In my article I will argue that the experience of schooling influences the children's and young people's visions of the future. My theoretical starting point is that children's and young people's visions of the future have to be studied in their social and cultural context, which is embedded in broader social change. Some studies have already depicted visions of the future among students ${ }^{1}$ in Africa, e.g. UNICEF in Togo (1971), Adick in rural Senegal (2003), and Spöhr in Tanzania (2010). Concentrating on students, these studies have not taken into consideration how children and young people who do not go to school imagine their future. During my fieldwork ${ }^{2}$ in southern Ethiopia, I asked children from agro-pastoral societies who did not go to school, students of different grades and ages, as well as students in villages and towns, about their visions of the future. Their answers reveal that visions of the future vary on a continuum between life as an agro-pastoralist at one end, and life in town with a job in the public sector at the other.

The first step of this article summarizes the findings of the existing studies on how students imagine the future and highlights the importance of such studies. After giving an overview of the study background and the history of formal schooling in southern Ethiopia, I will show with empirical examples how children and young people from agro-pastoral communities imagine their future. These visions can be classified into three groups: first, those of children and young people who have not been going to school, second, those of students who are going to school in rural areas while living with their families, and third, those of students going to school in towns separated from their families. I will argue that the visions of the first group of students are based on a cyclical notion of time that focuses on the reproduction of the

\footnotetext{
${ }^{1}$ In this article, I call all children and young people who go to school "students", no matter in which grade and how old they are. The study group of Adick and UNICEF are grade six students in their last year of Primary School. Spöhr's research is located at Secondary School level with students between 18 and 24 years of age.

2 This article is based on doctoral research conducted in Ethiopia over a total of 19 months between 2012 and 2015. My ethnographic study focuses on agro-pastoral students in South Omo Zone, particularly in Hamar Woreda, and looks at how they negotiate the two worlds of agro-pastoralism and formal governmental schooling. Many institutions and persons supported my fieldwork. I would like to thank the French Center for Ethiopian Studies, the Institute of Ethiopian Studies at Addis Ababa University, the South Omo Research Center in Jinka, the Friedrich Ebert Foundation and the Bayreuth International Graduate School of African Studies for their great support.
} 
agro-pastoral life world. The second group of students shows a mixed form of time concepts, whereas the third one stresses a linear time-reckoning, centered upon individual and national development. The last group consists, among others, of socalled hostel (boarding school) students who live in towns. Since the notion of "development" is central to the town students' visions of the future, the subsequent section seeks to discern what is emically understood by this concept. Given that students imagine a future different from the agro-pastoral way of life they grew up with, the question arises of where their visions stem from. While there are certainly many sources for these thoughts, I will focus on two which seem particularly pertinent, namely school books and advertisements for schooling. In a last step I will summarize children's and young people's dreams of the future with regard to their similarities and differences. ${ }^{3}$

\section{Perspectives on AfricAn STUdents' VISIONS OF THE FUTURE}

Before analyzing how children and young people from agro-pastoral societies in Ethiopia imagine their future, let me summarize existing studies on the futurerelated visions of students from various African countries. In 1971-1972, UNICEF conducted a study in eight West African countries. In this context, all grade six students in Togo, in total 11,500, were asked to write essays on their visions of the future (cited and compared in Adick 2003a, b; Spöhr 2010). ${ }^{4}$ In 1995, Christel Adick, a comparative educationalist, asked 40 grade six students in rural Senegal to write essays on the topic "Mon Avenir" (Adick 2003a, b), in order to understand the children's socialization process. Spöhr's anthropological research, conducted in 2001, explored how secondary school students imagined their future in the town of Mwanza, Tanzania by triangulating different quantitative and qualitative methods (Spöhr 2010). The three studies point to the following similarities:

Firstly, a negative future is rarely imagined, instead students mention a bright future and are very optimistic when thinking about it - even if the labor market in these countries would give them much reason for pessimism, at least since the 1980s (Adick 2003b: 243; Spöhr 2010: 109). Secondly, most students long for jobs in the public sector; they desire a monthly salary and do not want to make a living from subsistence farming as their fathers did (Adick 2003a: 42; Spöhr 2010: 101). Thirdly, to live in town, to own a big and well equipped cement house, a car and nice clothes, as well as having high educational aspirations and faith in progress characterize the students' view of their future in all these studies (Adick 2003b: 243; Spöhr 2010: 109;

\footnotetext{
${ }^{3}$ When talking about "future", respective terms and concepts in local languages have to be considered. In Amharic, for example, $\boldsymbol{\omega} \boldsymbol{S} \boldsymbol{b} \boldsymbol{b}$ (wede fiti) is an appropriate translation for "future". In Hamar, the language of one of the agro-pastoral groups of my study, a possible translation is uss birant, which refers to something "beyond and ahead" of the speaker's present situation.

${ }^{4}$ Title of the survey: «Prospective de l'Enfance et de la Jeunesse dans le Développement - Togo » (UNICEF Togo 1971) : Documents de Travail, Enquêtes et Rapports (2 vol.): Enfants et Jeunesse dans l'Espace Togolais (2 vol.), Lomé.
} 
UNICEF survey compared in Adick 2003b: 243; Spöhr 2010: 109). Spöhr highlights that students from rural backgrounds, whose fathers and mothers have little or no formal education, focus more on helping and supporting their families than middle and upper class students from town do (Spöhr 2010: 53-55). Similarly, the rural students in Adick's study expressed the wish to support their families, to ensure the meeting of basic needs and to live according to religious commands (Adick 2003a: 44). Finally, both in Adick's and Spöhr's account, a few students mentioned patriotic feelings (Adick 2003a: 44; 2003b: 241-242; Spöhr 2010: 109). As becomes visible throughout this article, the visions of students from southern Ethiopia point to similar aspirations.

Of course, the study of visions of the future does not allow us to draw conclusions about how the future is "really" going to look and yet, such visions may not be entirely unrelated to the shape the future takes. As Wallman summarizes findings from an ASA conference on "Social Anthropology and the Future": "Images of the future (may) affect what happens in the future; and, still more important, (...) images of the future (can) constrain the present at least as much as do images of the past. (...) They [these observations] imply that future orientation of some kind sustains everything we call culture or social organization - even that continuity itself depends on it." (Wallman 1992: 2)

Hence, visions of the future should not be disregarded. On the one hand, by depicting the future in a positive or negative light, they help us to grasp how people perceive their present. On the other hand, they show us the goals people strive to realize in their lives, and thus may give a hint of the direction of socio-cultural change. In order to understand and contextualize children's and young people's visions of the future in southern Ethiopia, some background data on their current living environment is needed.

\section{HISTORY OF FORMAL SCHOOLING IN SOUTHERN ETHIOPIA}

For a long time, southwestern Ethiopia has been regarded as a remote area, inhabited by very culturally and linguistically diverse groups of agriculturalists and agro-pastoralists. The latter cover their subsistence in the Ethiopian semi-arid lowlands mostly by breeding cattle, sheep and goats in mobile cattle camps and by cultivating maize and sorghum in slash-and-burn as well as in flood retreat cultivation on river banks. In the last fifteen years, the study area, South Omo Zone, ${ }^{5}$ has seen a strong growth in infrastructure, including road, school and health center construction, as well as large scale investments. In order to fulfill the millennium development goal of Education for All the number of schools has been increased by government and (inter)national non-governmental organizations. While the first

\footnotetext{
${ }^{5}$ In South Omo Zone 16 ethnic groups are formally recognized, of which 14 are agro-pastoralists. The latter are administered in 6 administrative units, called Woreda. These Woredas are: Banna-Tsamay, Dassanetch, Hamar, Maale, Nyangatom and Salamago.
} 
governmental school in Ethiopia was opened in the capital Addis Ababa in 1908 by Menelik II, the first Primary Schools in South Omo Zone opened in the 1950s with an evangelical mission school in Bako followed by Neri Primary School in Jinka in 1957/58 (Zonal Education Office Jinka, 23/05/2014). These two schools are situated in the territory of the Aari people, who are agriculturalists. The first schools in lowland areas inhabited by agro-pastoralists, were built at the end of the 1960s and during the socialist regime in the 1970s and 1980s (Lydall 2000: 43 and 2010: 323). During the last ten years the number of schools and students has increased dramatically. In 2008 the school coverage (Gross Enrollment Ratio, GER) in Maale Woreda, ${ }^{6}$ an administrative unit of South Omo Zone, was 33,88\% (Thubauville 2012: 221). Five years later in the school year 2013-2014 the GER had increased to $113 \% .^{7}$ In the same year it was still $34,7 \%$ in Hamar Woreda ${ }^{8}$ (Zonal Education Office, Jinka, 23/05/2014). These numbers have to be regarded with caution as the total population as well as the school age population and age in general can only be estimated. However, the growing number of schools is obvious in many settlements, starting with Alternative Basic Education (ABE) centers for grade 1 up to 3, ${ }^{9}$ and Primary Schools from grade 1 up to 4, 5, 6 or 8. High schools for grade 9 and 10 are located in Woreda capitals and Preparatory Schools for grade 11 and 12 are accessible in the zonal capital Jinka as well as since September 2014 in Maale Woreda. In South Omo Zone, government run hostels for pastoral students were built during the 1980s, mostly in Woreda capitals and in Jinka, to provide food and shelter for children from distant places and to enable them to receive (higher) education. With the expansion of formal education and growing infrastructure, agro-pastoralists are increasingly confronted with the Ethiopian state and the wider world. Against this background, my paper explores how children and young people from agro-pastoral communities imagine their future. My data was mostly collected in the zonal capital Jinka, where students from all agro-pastoral

\footnotetext{
${ }^{6}$ Maale people are agriculturalists in the highlands bordering Aari as well as pastoralists in the lowlands.

7 See https://datahelpdesk.worldbank.org/knowledgebase/articles/114955-how-can-gross-schoolenrollment-ratios-be-over-100 for an explanation of how GERs can be over 100\%.

${ }^{8}$ Ethnic groups found in Hamar Woreda are the agro-pastoral Hamar, Banna, Bashada, Arbore, and Kara. The growth of schools in Hamar Woreda is also highlighted by Save the Children Norway: Before 2004 there were no Alternative Basic Education Centers in Hamar Woreda and only 5 Primary Schools (Grade 1-4), 2 Primary Schools (Grade 1-8) and 2 Kindergartens. At the end of the year 2010, after Save the Children's intervention, there are 38 Alternative Basic Education Centers, 16 Primary Schools (grade 1-4), 5 Primary Schools (1-8) and 17 Kindergartens (Zeleke \& Zeleke 2012: 22).

${ }^{9}$ Alternative Basic Education (ABE) Centers use textbooks with local names for people and places, but follow the same regional curriculum. Another characteristic of ABE is that the school buildings are made of wood and not cement.
} 
Woredas come to the hostel, as well as in Hamar Woreda. ${ }^{10}$ In order to ensure confidentiality, I use pseudonyms when citing my informants. ${ }^{11}$

\section{VISIONS OF THE FUTURE AMONG NON-SCHOOL CHILDREN AND YOUNG PEOPLE IN RURAL AREAS}

Until recently, most children in agro-pastoral areas did not go to school, but spent their time learning and helping in the family economy. In a Hamar village, three hours walk from the next town, I asked a girl, aged around 18, about her future. She explained: "Now I am anza [an unmarried girl]. Later I will marry and I will become gol [a married woman]. I will bear children. I will grind flour, work in the fields, and collect firewood and water. I will cook and care for the house and when guests come, I will serve them coffee." (Conversation in Hamar, 01/12/2014)

Even if not asked, unmarried girls sometimes told me that they would bear children, who would suck at their breasts. By this they emphasize their future role as mothers. These descriptions of future activities do not contain any negative views about living an agro-pastoral life. Instead, these visions of the future reflect the actual social organization of the community and the division of tasks according to age, gender and status, and so these girls strive to live like adult Hamar women do at present.

Similar conceptions of the future as a repetition of the present have often been linked and attributed to a cyclical understanding of time (Wallman 1992: 11). This cyclical concept is often contrasted with a linear one, as Bloch explains: "On the one hand we have concepts rather like our own folk everyday concept of linear durational time and on the other hand a concept of a static notion of time often referred to as cyclic." (Bloch 1977: 282)

As it is tempting to conclude that each culture knows only one of these two time concepts and that linear time concepts can be found in "industrialized societies" and cyclical ones in "non-industrialized societies", Bloch (1977) argues that both concepts can exist within one culture depending on varying communication situations, like ritual or agriculture. ${ }^{12}$ The question central to many debates on time (Bloch 1977; Bourdillon 1978; Howe 1981; Munn 1992) is, which notion of time is applied in which

\footnotetext{
${ }^{10}$ The population in Hamar Woreda is estimated at around 75,056 people of which 3,567 live in the three towns Dimeka, Turmi and Arbore Town (Hamar Woreda Administration, Dimeka, 24/03/2014).

${ }^{11}$ The interviews and conversations were conducted in the Hamar language, English and partly in Amharic. Most of the cited interviews were conducted without the help of translators.

12 The dualistic nature fundamental to anthropological thinking is best described by Wiseman (2001) for Lévi-Strauss' distinction of "hot and cold societies" and their linkage through chiasmic reversion. Bourdillon (1978) criticizes Bloch's binary opposition which, though having tradition in western theories about time (Munn 1992: 101), did not fit the social reality he observed in the Balinese society. The binary opposition between two kinds of time reckoning is overcome in Howe's work (1981) which argues that there exists only one understanding of duration within each society, which has both cyclical and linear elements (Munn 1992: 101).
} 
(context of) society. My case study of agro-pastoral societies in southern Ethiopia will show that, among children and young people, two different time concepts exist with regard to the future, and these are related to different social contexts, that is, agropastoral households and school.

Children and young people who have not been going to school imagine a future life similar to the present one, with the only difference to their present situation being that they themselves will grow-up and experience status changes. Thus their vision of the future depicts a life path with certain steps that could be described as a linear process of growing up. However, overall, the future life that they picture is similar both to that of their forefathers and that of the present. I therefore call the time concept that underlies their vision of the future "cyclical", since they envision maintaining the present social and cultural organization in the future (Wallman 1992: 11).

A first argument for this cyclical notion of time is that children and young people who have not attended school wish to follow an ideal life path with central rituals of status changes that recur generation after generation. ${ }^{13}$ As we have seen above, cyclical notions of time can be connected to "stasis" (Bloch 1977: 282). But of course, the presence of cyclical time does not mean that societies are "frozen" (Azarya 1996: 11). Societies like Hamar are always changing, e.g. in regard to fashion, clothing and body adornment, as well as to technological inventions like the introduction of the oxplough (Strecker 2005: 985), mobile phones and grinding mills. This kind of change, however, is not addressed in the visions of the future of children and young people who have not been going to school. Thus, while reality may be marked by change, the ideal expressed in people's future vision is one of continuity. ${ }^{14}$

A second argument for cyclical notions of time can be found in the existence of age-sets. ${ }^{15}$ With regard to visions of the future, Baxter and Almagor summarize the conservative effects of age-systems as follows: "Age-systems are, but not only, means of holding time past in a steady relation to time present and to time future; a sign of the enduring past which endures through the present and into the future. They place past, present and future in perspective and provide an individual with hopes for a future similar to the past." (Baxter \& Almagor 1978: 23)

\footnotetext{
${ }^{13}$ For Hamar coming of age and its initiation rituals see Baldambe's explanations in Lydall \& Strecker (1979). For Bashada see Epple (2010).

${ }^{14}$ As my argument is not about one notion of time in a single society, but about differing notions of time within different social contexts, I cannot follow Strecker's argument (1995) that the Hamar do not have a cyclical notion of time at all.

15 For discussions on time and the reckoning of history in age-set-societies see also Evans-Pritchard (1939), Baxter \& Almagor (1978).
} 
Some of the people I talked to during my research in Jinka and Hamar Woreda were from societies featuring elaborate age-set systems. ${ }^{16}$ The existence of age-sets may not be a sufficient cause for the existence of cyclical time-reckoning. Empirically, however, this has often turned out to be the case (Schlee 1990; Zittelman 1990; Amborn 2004) $)^{17}$ and the above quote from Baxter and Almagor suggests the same. At least for the interviewed students from Arbore, Bashada, Dassanetch, Kara, Mursi or Nyangatom it therefore does not seem unlikely that their cultures contain an age-set related cyclical notion of time too. The case of Hamar is less clear in this regard. According to Strecker, there are no age-sets in Hamar as they gave them up after having been conquered by Menelik II's troops at the end of the $19^{\text {th }}$ century (Strecker 1976: 386; 2005: 984). During my fieldwork it turned out, however, that age-sets do exist although people acknowledged that they used to be more elaborate in the past. ${ }^{18}$ Apart from the extent to which an age-system is still working, we can assume that some features of rhythmic repetition are maintained. Amborn, for example, describes the Burjis' cyclical repetition of age-sets within the Gada system as being a model for time itself. Although the Burji gave up one of two parallel Gada systems during the last century in response to the conquest of Menelik's troops, they have maintained one system and some features of the other to calculate time (Amborn 2004: 389). Despite the clear cyclicity, Amborn also does not describe the time concept of the Burji as static, but as moving in ascending circles like a spiral (Amborn 2004: 392). It is not possible to make any direct inferences about the case of Hamar from these examples. Yet it is clear that given their previously elaborate age-set organization, which to some extent continues to exist in the present, further investigation could well reveal the existence of elements of cyclical repetition and associated notions of time. "Hopes for a future similar to the past" (Baxter \& Almagor 1978: 23) is what we have seen in the statements of children and young people who have not been going to school. Thus continuity and cyclicity of social and cultural organization sustain

\footnotetext{
16 Age-sets are found in Arbore (Gabbert 2012), Bashada (Epple 2010), Dassanetch (Almagor 1978), Kara (Gezahegn 2000), Mursi (Turton 1978) and Nyangatom (Tornay 1981). For Banna, age-grades are reported (Masuda 2003).

17 A cyclical notion of time in the Gada system of the pastoral Borana Oromo is identified by Zitelmann. He describes the concept of $d a c^{\prime} c^{\prime} i$, in which history is believed to repeat itself every 280 years (Zitelmann 1990: 63). Schlee (1990: 78) highlights the cyclical concept of daji among the Rendille in Northern Kenya. Daji is said to cause every third age-set (grandfather and grandson) to experience the same fate and fortune and to share the same character and powers. The strong belief in the repetitive character of age-sets is best shown when people do not want to give to the next generation the age-set name of a previous generation that had suffered from wars, drought and famine. By choosing a different age-set name they try to eliminate the bad fate attached to the name, though without success as Schlee (1990: 73) and Amborn (2004: 392) report.

18 Apart from that it would be astonishing if the Hamar who form a cultural and linguistic cluster with the neighboring Bashada (Lydall 2005), whose age-sets are documented (Epple 2010: 71-72) and Banna, for whom age grades are reported (Masuda 2003) had a completely different notion of ageorganization and time, although they often intermarry and are in close contact.
} 
their vision of the future. The following section shows that this ideal is also, to some degree, part of rural students' future visions.

\section{VISIONS OF THE FUTURE AMONG RURAL STUDENTS}

Aike is a Hamar boy aged around 12 years who lives in a village two hours walk away from town. In the morning he attends grade five in a nearby village school, in the afternoon he helps his family with their animals and fields. Interestingly, when asked about what he wants to do by the time he is an old man, he described the daily activities of an elder: "In the morning while drinking coffee a donza [elder] calls barjo [good fortune] and blesses the country. Then he works in the fields, he eats and has a rest, and he works again in the fields. In the evening he has a look at the cattle and goats in their respective kraals." (Conversation in Hamar, 22/04/2014)

When asked about his future, Aike described daily activities of grown-up men, just as the above mentioned girls spoke about the tasks of grown-up women. Despite going to school Aike sees himself in the future as doing what elderly men do at the moment. He is able to give a clear account of how his life will look when he has married and fathered several children. However, not all students in rural areas imagine their future in similar terms.

One evening, outside the goat enclosure in a Hamar settlement three hours walk away from town, I asked Gaito, a grade 4 student in the nearby village school, what he wants to do in the future. He replied that he wanted to become a teacher. Further asked if he will herd goats, he replied that he would herd goats as well. One of his friends, Bitta, a grade 5 student at the same school joined our conversation and I asked him what he wanted to do later on. Bitta said he would herd cattle. While saying this, Gaito whispered into his ear to say that he would become a teacher. Following the hint, Bitta repeated that he would become a teacher. While I was still asking the two why both of them wanted to become teachers, a third boy, Haile, around the same age joined our talk. Haile explained to the two boys that they would finish primary school, then high school and that eventually they would go to college or University in a bigger city like Arba Minch or Awasa (Conversation in Hamar, 01/12/2014). Interestingly, Haile, who had explained the educational system so well, did not go to school himself. Instead, older family members who had attended school seemingly had explained the educational steps to him of which the actual students were not yet completely aware. Bitta knew that being a teacher is a profession that students can do immediately after finishing grade 10 . The way in which he incited a fellow student to correct his vision from herding cattle to becoming a teacher shows which answers are thought of as being appropriate. In times where international policies promote "Education for All" and national policies force pastoralists to send all their children to school in order to develop and become "modern", the goal to remain a pastoralist is officially highly discredited. This devaluation notwithstanding, young students living with their pastoral families imagine themselves herding animals in the future, be it full-time or part-time. 
In the same location, older students above the age of twenty, despite only being in grade two or three, imagined that later they would become doctors, have a house in town and own a car. These wishes stand in opposition to their previous lifestyle, in which they used to be exclusively concerned with agro-pastoral work. At the moment, like nearly all rural students, they do not attend class every day, but sometimes fulfill agro-pastoral tasks and sometimes visit school. However, what seems to count for them is the idea that by going to school - no matter how old they are and how much or little they study - they will have access to a life in town with all its promises of luxuries.

When I asked Haile, whom I have mentioned already, if he later wanted to go to school, he confirmed this. I further asked, what he wanted to do in the future and he explained: "If I go to school, I will do gal work. If I am not going to school, I will herd cattle and goats." (Conversation in Hamar, 03/12/2014)

Gal is a term Hamar use to describe people from highland Ethiopia (Lydall 2010: 324), who call themselves Habesha or Amhara (Donham 1986: 23). According to the Hamar's view, gal are people who wear clothes, not leather clothes or blankets, who have a different hairstyle, which does not make use of ochre or clay adornments, who speak the national language of Amharic, follow different customs, a different religion and work to earn money and make a living in a market economy without rearing cattle.

In this sense "gal work" refers to labor outside of the pastoral economy, e.g. in the public or private service sector. By distinguishing between "gal work" and herding cattle, which is a synonym for pastoralism, Haile illustrates the idealized future pathways of students and non-students. However, for students in rural schools, who get formal teaching in the morning and help their families in the afternoon, these visions are often entangled rather than distinct. It is only in the course of advancing further in school and moving to town that students' visions of the future start to differ more clearly from those to be found among young people in rural areas.

\section{VISIONS OF THE FUTURE AMONG URBAN STUDENTS}

In a conversation with Aska, a 20-year-old grade 8 student, who went to school in a town with about 2000 inhabitants, he explained to me the difference between Hamars' and students' visions of the future:

"Sabrina (S): In Germany, young people think a lot about their future life. What they are going to do, where they are going to live, what job they are going to do. Do Hamar also think like this?

Aska (A): When maize and sorghum are growing well, when there's plenty of maize and sorghum, Hamar sell it and buy goats. When they have many goats and cattle, men think about marriage. They look for goats and honey and give it to the family of the bride. If there is no rain and no grass for the cattle, they think where grass could be left and where to go with their cattle to feed them. That's what Hamar think of.

S: And what do students think when they think about the future?

A: Maybe I will go to high school, maybe to college or university. Maybe I will find work in town. Then I will rarely go to the village to plough the field." (Conversation in Jinka, 12/05/2014) 
In discussions with children and young people from agro-pastoral families who are going to school in town, they emphasize that their parents only care about cattle and goats. In contrast to this, they consider themselves as temari, ${ }^{19}$ a student. They are recognized by their families and teachers as such and no longer as pastoralists. As students they claim to know things outside of the agro-pastoral horizon and territory. They do not clearly know what job they will do in the future, as they think of many possibilities outside the agro-pastoral economy, but they are sure that they will not herd animals and work in the fields full time. Thus, their vision of the future shows that maintaining the social world of agro-pastoralism in general, and personally leading an agro-pastoral life in particular, does not seem desirable. Details

\section{Hostel students' visions of the future}

As only a few students from agro-pastoral families can afford housing and living expenses in town, government run hostels were established during the 1980s in zonal and Woreda capitals of South Omo Zone. ${ }^{20}$ They are exclusively for pastoral students and provide a bed with a mattress, simple food common to highland Ethiopia, as well as school materials, like exercise books, pens and to a varying extent school uniforms. In addition to many conversations, I asked 50 students in the hostel in Jinka to answer a questionnaire, included in which I asked what they wanted to do in the future after school. Most of these students attend grade 11 and 12 of preparatory school after which they can proceed to university. Only three girls wanted to fill in the form, so that my analysis mostly reflects male visions of the future. ${ }^{21}$ Using a questionnaire proved to be very challenging in this context. From grade 5 onward and except for the subject "Amharic", English is the official language of instruction in South Omo Zone and all school books are written in English. Nevertheless, the majority of teachers and students are not used to speaking and writing English and their understanding of English is very limited. Therefore, the students helped each other to translate the questions into Amharic. Despite my explanation to the contrary, the students considered the questionnaire a test, in which their answers would be rated as "true" or "false". In order to assure them that I understood their answers correctly, I read the questionnaire together with each student and added some notes or corrected their English to clarify their intended meaning. In the

\footnotetext{
${ }_{19}$ Amharic words that are also used in Hamar, although slightly adapted to Hamar grammatical use, are transcribed into Latin letters following the list from the Journal ITYOPIS (http://www.ityopis.org/Guidelines_files/ITYOPIS-I-Transliteration.pdf). Hamar words are also written in Latin to make reading easier.

${ }^{20}$ Today there are seven government run hostels for agro-pastoral students in South Omo Zone. In the school year 2013-2014 they hosted around 1,500 students (Zonal Education Office, 23/05/2014, Jinka). ${ }^{21}$ In March 2014, the Jinka hostel had 98 registered students out of which eight were girls (03/03/2014, Jinka Hostel). In most Woredas the number of schoolgirls are much lower than that of boys. Only if school feeding programs supported girls' attendance, e.g. by giving two liters of oil every month to the family of school girls, might the number of girls' increase and even exceed the number of boys. This was the case in Maale Woreda in 2014.
} 
following I will analyze their answers to the question: "What do you want to do in the future/after school?" Some students mentioned several future activities, so that in total 54 occupations were counted. Of these, 16 concerned work in the field of health, e.g. as a doctor, nurse or health extension worker. ${ }^{22}$ Six occupations related to working for the country and helping the family, ${ }^{23}$ five to the domain of administration and management, ${ }^{24}$ "Finishing school," "going to university" and "working in the field of law" were each mentioned three times. "Teaching pastoralists" and "changing pastoralists" appeared twice respectively. One student wanted "to learn more" and another "to go abroad". Finally, the following six occupations were each mentioned once: to drive a car, to study sport science and nutrition, to become a sociologist, a journalist and tourist guide, an engineer and an “economics man" (Questionnaire, 11, 13/03/2014, Jinka).

Interestingly the findings of the questionnaire differ from the responses students gave during conversations we had had on other occasions. Reasons for this could be difficulties in understanding and writing English, as well as the expectation that their answers would be marked as "true" or "false". I therefore asked a grade 11 town student with excellent English skills to fill in the questionnaire. Some days before, she had told me that she wanted to become a nurse. In the questionnaire, however, she answered the same question by writing that she wanted her country to develop and become one of the biggest in the world (19/03/2014, Jinka). This example confirms that written answers are framed differently than in personal conversations. Instead of stating their personal opinion, students emphasize the future of the Ethiopian state, its development and their leading role in this process. As one student put it: "After school I lead my country, I support my family and I manage myself." Another wrote: "I want to be health professional to manage people and whole of Ethiopian citizens and to manage them in a good way." (Questionaire, 11, 13/03/2014, Jinka) These visions reveal how students regard themselves as an important part of the state and their future as linked up with managing and developing the Ethiopian national state. Ethnographic studies of schools in other developing countries have already shown how states try to use education to promote national culture and unification in order to diminish the significance of local culture and to create unified citizens of the nation-state (Stambach 2000; Coe 2005; Fuller 1991). Some effects of this process can be seen in this case study, when students emphasize their loyalty towards the state.

However, in personal conversations, the students neither mentioned the national dimension of their future activities nor the desire to become a leader or

\footnotetext{
22 Examples: "I want to become a doctor, so I help my families by educate and support by money."; "Assisting and supporting people who are suffering from physical and psychological problems, opening a clinic/hospital in rural area. To avoid the death of peoples and decrease mortality rate."

${ }^{23}$ Examples: "I will support my family, I will support my people, our country."; "I finish university and take my first degree and I help my family and other depending people. That is my vision."

${ }^{24}$ Example: "I like to be administrator to the country."
} 
administrator. This is a reason to think about the methodology we use when investigating visions of the future. In conversations, the three most often stated future professions were: doctor, pilot and engineer, ${ }^{25}$ Generally, when asked about their future, students answered that they wanted to finish school and go to university. It should be noted that being able to finish school is not a matter of course for them: Not only do students face a lack of materials and teachers, but especially hostel students in towns have unfamiliar and insufficient food and clothes and suffer from frequent illness. ${ }^{26}$ The majority of the town students want to return to their home area after graduating from university. However, they highlight that they do not want to live as pastoralists, but to help their families by earning money from a job. As a reason for not living an agro-pastoral life, they argue that they are temari. Here temari refers to a person, who has "learned", which means that she knows how to read and write, has put on clothes and therefore does not want to go "back" to pastoral life, as the latter is considered "backward". In this context the skills and knowledge children acquire in an agro-pastoral life are not considered as "knowledge".

The way students set themselves apart from agro-pastoral or farmers' lives shows a clear break with their origin. The town students' vision of the future stresses development and change. This wish indicates an underlying linear time concept, in which the future is imagined as entirely different from past and present. Mains, whose research explores the hopes of unemployed young people in the Ethiopian town of Jimma, draws a link between students' linear time concept and formal education: "I argue that the progressive nature of young men's hopes is related to the expansion of formal education that began in Ethiopia during the mid-twentieth century. The importance of education in securing employment and the intrinsically progressive nature of the education process led many young men to expect linear improvement in their lives." (Mains 2011: 68)

That this expectation is not easily fulfilled in reality can be seen in the high number of young "educated unemployed" people queuing for jobs in many parts of the world (Mains 2011; Jeffrey 2010). However, the belief in education to bring progress and to improve one's life persists. A theme often addressed by school studies is that, through school, peoples' life paths change. Dyer (2010: 64) observes

\footnotetext{
${ }^{25}$ Also a 90-year-old woman going to school in Kenya states: "With education you can be whatever you want, a doctor, lawyer or a pilot." (BBC News, 23.01.2015: http://www.bbc.com/news/worldafrica-30935874). The fact that this woman names the same professions as do students in southern Ethiopia, gives reason to ask further questions regarding the expectations created by schools in developing countries.

${ }^{26}$ The high drop-out rate is best seen in the few students from agro-pastoral families that have been able to finish grade 10 or 12 and continued to college or university. Only around 10 students from Hamar have received a University degree so far. Epple's research, for example, describes that from the highly motivated students that went to school in Bashada in 2007, almost none remained in school four years later (Epple 2012: 208).
} 
that nomadic children have to decide which kind of knowledge they want to acquire: the knowledge taught in formal schools by teachers or the one they learn "on the job" in the family economy. Both ways of learning are not compatible at the same time and are later hard to reintegrate. Alber (2012) also describes the differences between school and working childhoods in Northern Benin. Children working in the family economy are more likely to stay at home and thus ensure that their parents are looked after when they get old. Generally, children going to school later migrate to towns and are no longer available to the family economy. Other school ethnographies describe how school changes the identity and children's sense of belonging. "The desire for education is a desire to become other in all kinds of ways", states Simpson (2003: 191), whose research is located at a Catholic Mission School in Zambia. Through the teaching and the whole organization of the school, the students learn to see their original families in a different light:

"They [the students] became, I [Simpson] would argue, strangers to themselves. St Antony's thus manufactured distance through the creation of difference and distinction. Several students told me how their experience of mission secondary life had deeply affected the way they saw the lives of their parents, brothers and sisters who had failed to get into school. Indeed, some explained that a visit home became a painful experience, when they saw, as if for the first time, the misery of the lives around them. The message of the school was that their life would be quite different, if they applied themselves. They could climb the ladder out of this misery." (Simpson 2003: 83)

This example clearly shows how young people develop a different perspective on their natal families and pre-school life during formal schooling (Göpfert \& Noll 2013). The "misery" they start to see in their environment shall be overcome by formal education, which is supposed to be a door opener for becoming middle and upper class citizens. As the concept "development" is so central to the town students' visions of the future, a closer look at their understanding of development will be given in the following chapter.

\section{STUDENTS" NOTIONS OF “DEVELOPMENT"}

One afternoon I gave a picture dictionary for Amharic and English and a magazine from the German Railway to some high school students. After looking intensively at the photos of houses, cities and landscapes the conversation took the following course:

“Student 1: Everyone, every child in Hamar should learn. Then we are developed.

Sabrina (S): What happens, when you are developed?

Student 1: Then we lead a modern life.

S: Do you think a modern life is good?

Student 1 and 2: YES, YES, it's VERY good!!! (eyes shining full of promise)

S: How does it look like? 
Student 2: Everyone has a job.

Student 1: Everyone is educated. There are no longer any dambi [traditions, customs].

Student 2: Dambi sienne [Traditions are bad]. There will no longer be any leap across the cattle [initiation ceremony for young men], there will no longer be any beating of women [as part of initiation ceremonies]. There will no longer be any memorial feasts. All these are bad. When you make rituals and you slaughter goats, ALL this is bad.

Student 1: If everyone is educated and there are no dambi [traditions, customs], it has an effect on the economy. I will learn and then I will become an engineer, or a pilot or a doctor.

S: But if you say, Germany is developed, there are also people, who have no work, who have no house, who have nothing to eat. (stunned astonishment)

Student 2: How? You learn, you become a doctor and then there is no work?

S: For doctors there may be work, but not for everyone. For example, there are many teachers, and not all of them get employed. Then they have no job. (break: students are wondering and do not continue speaking). How would it look like, if agro-pastoralists are modern?

Student 1: If you breed cattle in a modern way, the number will increase. We need tractors for farming. Now there is not always rain. If there is no rain, the cattle die. So we need generators to pump water for the cattle." (Conversation in Dimeka, $15 / 10 / 2014)$.

In this conversation the students' understanding of development ${ }^{27}$ as depending on formal mass education and the stopping of cultural practices becomes explicit. Here the students want formal education for everyone and to put an end to the sociocultural practices on which the agro-pastoral world is built, but which they regard as a hindrance for development. The envisioned transformation out of the present day situation for themselves and their society is something they regard as unquestionably good. They think that widespread formal education automatically leads to jobs for everyone. However, while rituals e.g. the initiation of young Hamar men, who leap across a row of cattle, attract many tourists and thus generates income, it is so far unclear how the absence of these rituals will create jobs for all formally educated people. While the unemployment rate is not (yet) very high in pastoral areas, it is very high among young people in other parts of rural and urban Ethiopia (Mains 2011). Almost all teachers in Hamar were forced to move from the Ethiopian highlands to the lowlands in order to find a job, as they could not get one in their home area. As far as I have seen, there is not yet a single medical doctor from an agro-pastoral background and only very few agro-pastoralists who have been to University. Most students become teachers or go to colleges and later work in the local administration. The students know that first year primary school teachers only

${ }^{27}$ In South Omo Zone the English terms "development" as well as "change" are frequently used by students. 
get a salary of around 1,000 Ethiopian Birr per month from which they struggle to live. ${ }^{28}$

As Mains' study shows, the dreams of school graduates may be shattered once they meet reality. Even the unemployed young people in the town of Jimma who have attended secondary school do not experience the progress they expected. Instead their "hope [for a bright future] is cut" (Mains 2011). Many young people in Africa as well as in Europe, North America, India and other countries are in a state of "waithood", in which they are waiting to find a job and to become independent and able to reach adulthood (Honwana 2014). However, this harsh reality is not included in the thoughts of the future expressed by the students in urban southern Ethiopia. Their vision of the future is characterized by development, which entails a linear way out of the present day situation. This understanding of future time opposes the circularity and continuity that children and young people who have not been to school, or only for a few years, envision. In fact, a teacher's life, like most jobs, is quite repetitive in its daily teaching and with each school year following another. Only slowly can a teacher experience progress and increase his salary by additional training and more years of work experience. However, from the perspective of the students, their experience of what a teacher does differs from their knowledge of what an agro-pastoralist does. For them it is therefore not repetitive, but compared to the agro-pastoral life a symbol of development. The means to alter children's vision of the future are manifold and cannot be named in detail here. However, the following chapter provides some sources of students' thoughts of the future.

\section{SOURCES FOR STUDENT'S VISIONS OF THE FUTURE}

One may ask where the students' progressive vision of the future stems from. One answer can be found in school books and advertisements that provide students with images of the future.

The patriotic attitude students have expressed, reflects the values taught in the subject "Civics and Ethical Education". Running from grade five to university level, "Civics" contains the following units which recur year after year: Democratic System, The Rule of Law, Equality, Justice, Patriotism, Responsibility, Industriousness, SelfReliance, Saving, Active Community Participation and The Pursuit of Wisdom. Through this subject, students are taught national norms and values, like the organization of the federal system, the rights of Ethiopian citizens or ideas about equality. The content of the curriculum also emphasizes the duty of Ethiopian citizens to work for their country and to help it advance from an underdeveloped to a developed state, be it through saving, self-reliance, industriousness or community work. By this, the individual's future is linked to, and seen to depend on, the

281000 Birr is around 25 Euros. To have an idea of the price level, a reasonably good pair of trousers costs 500 Birr. 
country's future development. It is therefore not surprising that the students envision a future that fits into this national development plan.

For people of the southern Ethiopian lowlands the identification with the Ethiopian state is a recent phenomenon, since for over a century they were fighting against invaders from the northern highlands (Donham \& James 1986; Strecker 2013). Until the 1970s the highland Ethiopians called people of the south shank'illa, which can be translated as "black people" and "slaves" living in the southern "wilderness" (Amborn 2005: 2; Donham 1986: 12-13). Despite the discredit into which this term has fallen, the paternalistic attitude of highland Ethiopians towards people in the south, which it reflects, has not disappeared (Lydall 2010). At the same time, I could observe how Hamar people themselves distinguish on a daily basis between Hamar and gal (highlanders). Against this background it is significant that in their visions of the future, town students perceive themselves as part of the Ethiopian nation-state, which is equivalent to considering oneself a highlander. Pastoralists, on the contrary, discuss if a temari (student) is an original agro-pastoralist, has become highlander or is somewhere in-between. At this point a detailed description of the identity-related negotiations of students from agro-pastoral backgrounds cannot be given. ${ }^{29}$ The important point to highlight is that their exposure to national development ideologies does not only affect their identity but also their time concept. One source for the change from cyclical to linear notions of time can be seen in the following example:

Figure 1: English Book: "Personal Future Plans"

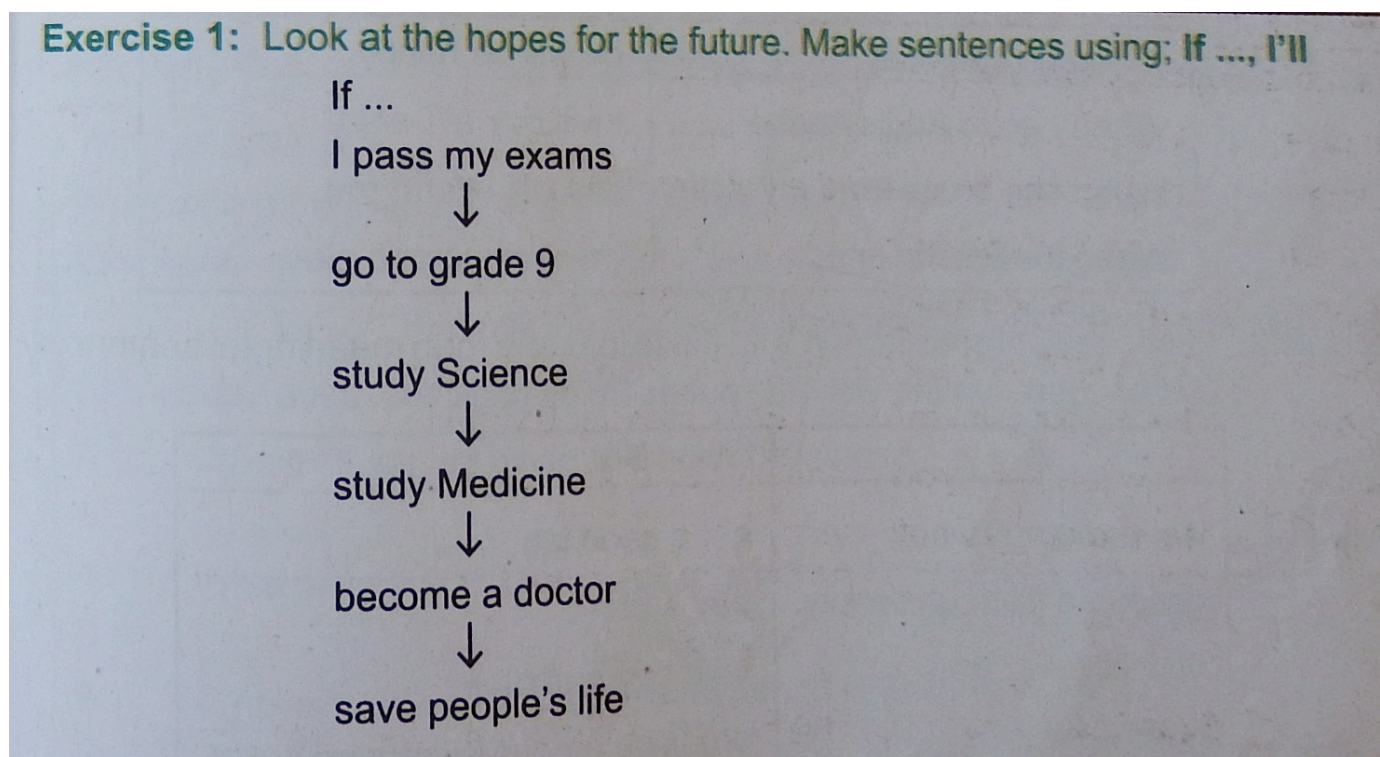

Source: English for Ethiopia. Student Textbook. Grade 8. Federal Democratic Republic of Ethiopia. Ministry of Education (2003: 77).

${ }^{29}$ For discussions about identity among Mursi school girls see LaTosky \& Zehle (2012). Niebling (2010) also discusses some of the dilemmas students from Hamar face. 
This exercise is found in the English book of grade eight, Unit 6: "Personal future plans". The first conditional is introduced and practiced with this idealized future life path of becoming a doctor and this is exactly what the majority of the students answered in the questionnaire when asked about their future. The book contains other units like "Education for all" (Unit 4) and "Technology in a Modern World" (Unit 12), the contents of which are expressed in students' visions of the future, when they say they want to teach illiterate people and want pastoralists to use technology instead of working their fields by hand. While there is a clear correlation between these teachings and students' answers, we cannot exclude the possibility that other factors have shaped their visions of the future, too. However, the vocabulary of the Civics and English books is easily recognizable in people's spoken English. Given what we know about the effects of language use on our perception of the world (Whorf 1956; Bloom \& Keil 2001), this indicates the extent to which students' thinking is shaped by these books and teaching.

The work students expect in the future is best illustrated by a poster at a primary school entrance:

Figure 2: School Sign: "Today we learn, tomorrow we work!"

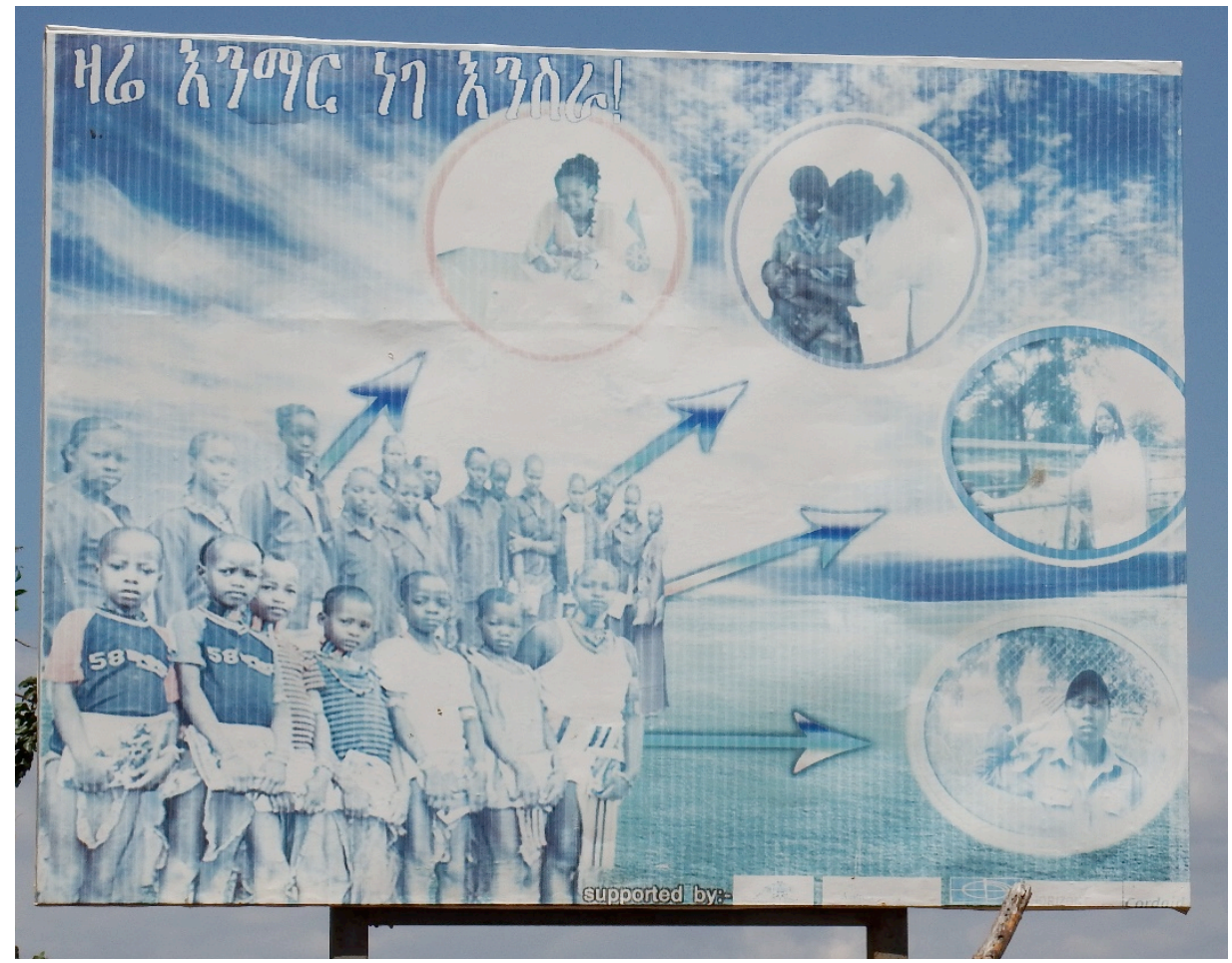

Source: Primary School in Hamar Woreda (photo by S. Maurus 2014).

The Amharic appeal "Zaré 'inimari nege 'inisira!" can be translated with: "Today we learn, tomorrow we work!" The depicted group of children with clothes are typical representatives of schoolchildren who are directed to jobs as health workers, judges and policemen. The photographs show real role models, as they depict former students from Hamar who now hold such positions. This poster reminds the 
students on a daily basis about their expected future in public services outside the agro-pastoral family economy.

Another expression of the progressive nature and expected effects of education is symbolized by the following sign located in Turmi town on the way to Primary School:

Figure 3: School Sign: "Let's minimize unprogressive tribal custom through education"

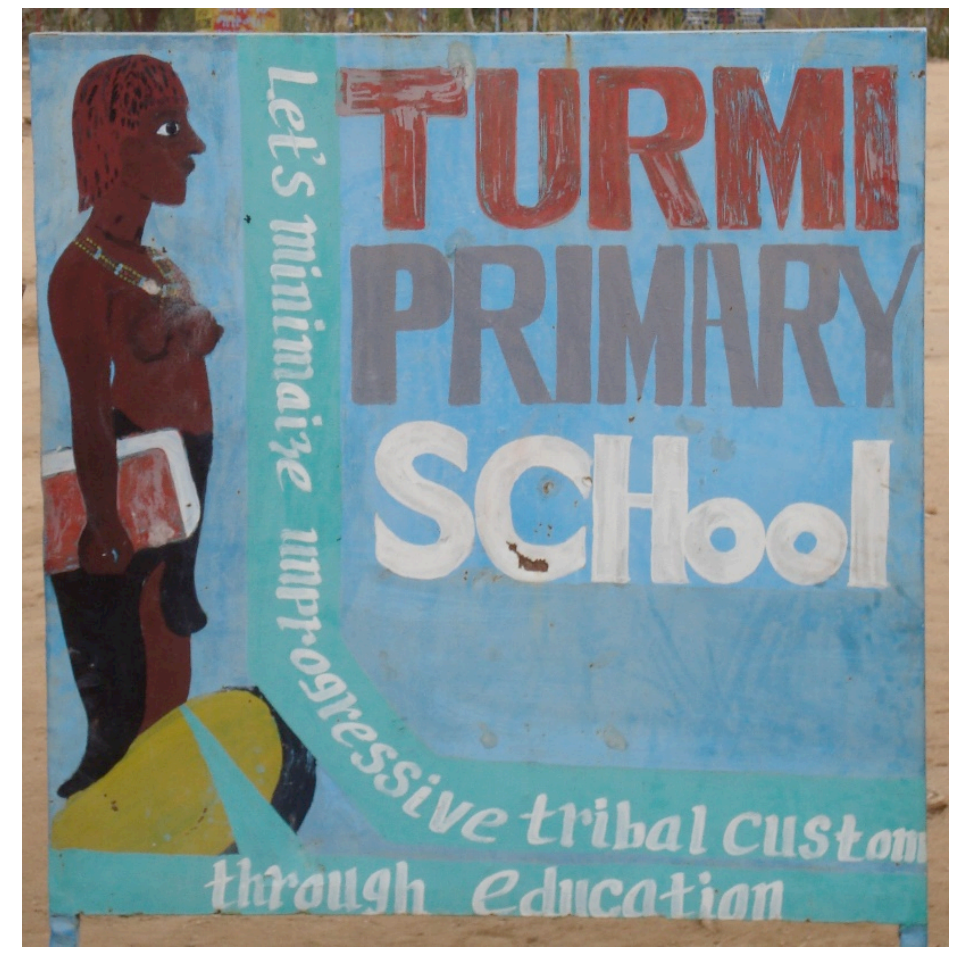

Source: Turmi Primary School in Hamar Woreda (photo by S. Maurus 2013).

The inscription says: "Let's minimize unprogressive tribal custom through education" and depicts a girl or woman with traditional Hamar hair style, a skirt but no shirt and a book. The book symbolizes formal education and the change it is supposed to bring to the "tribe". Such depictions provide an explanation of how the future comes to be imagined as described above.

Besides differing images of the future among children and young people there also exist some that are shared by children and young people, no matter if they have been to school or not. These similarities and their slight differences will be discussed in the following closing chapter.

\section{(Dis)SiMILAR DREAMS OF THE FUTURE}

A number of dreams are common for people with and without school experience. They all would like to visit bigger cities, like the capital Addis Ababa, or a "developed" country in Europe or America. Especially machines and technologies attract a lot of attention. Students can spend days watching excavators and road rollers and they ask who can make such machines and if they are not created by God. An argument often used by government employees to persuade people of the benefit 
of education, is that students know how to make and use machines. Accordingly, parents told me that one reason why they send their children to school is that they learn what they themselves do not know, for example the use of mobile phones, motorbikes and cars. Thus, students as well as non-students are interested in getting to know foreign places and technologies and to integrate the latter into their future lives.

Another shared future vision of children and young people is marriage. Everyone I asked wants to marry and have children. However, to whom and in which way they want to get married differs and is often a source of conflict. In general, in the agro-pastoral societies studied, parents arrange the first marriage partner for their sons and daughters. However, girls in the Hamar hostel said that all of them, numbering 60 in the school year 2013-2014, want to choose their future husband themselves. In school, they said, they are told about their rights. Therefore, they know that they can make their own decisions and even go to court (Group Discussion, 27/03/2014, Dimeka). Some of the already engaged girls ran away from home to escape an arranged marriage and sought refuge in the hostel. (Inter)national policy promotes girls' education and so family members who want students to leave school and marry are threatened and taken to the police (Thubauville 2012). In contrast to this, some girls do not refuse to marry their assigned husband and while their age-mates are still going to school, they move to their husband, have their first child and become the mothers and wives they wanted to become. This is the same for boys who do not go to school or only attend for a few years. After they drop-out after a number of years, they continue herding cattle full-time and start their own family in the countryside.

Most male students support polygyny, in that they want to marry one girl from their ethnic group, who the parents choose and another woman they pick themselves from outside their usual marriage unit, e.g. from town or from abroad. In this way they want to combine the worlds of pastoralism and town life. However, students converted to Protestantism or Ethiopian Orthodox Christianity claim to refuse the marriage of several women and thus oppose a practice highly valued in agropastoral societies. Furthermore, Protestants claim to reject all "traditional" practices and therefore refuse initiation, including the initiation required for marriage. Apart from this latter group, boys have the possibility to follow the traditional way of marriage and additionally marry a woman from outside their group, if this woman agrees to be the second wife. In contrast to this, girls can only marry one legitimate husband and therefore have to decide if they want to live in town or lead a rural agro-pastoral life. ${ }^{30}$

\footnotetext{
${ }^{30}$ A study of Lesorogol shows that female primary school graduates among the Samburu pastoralists in Kenya only manage to draw symbolic lines between themselves and non-school girls. In the end they do not really manage to set themselves apart from pastoralism, but put off their modern clothes and agree to arranged marriages (Lesorogol 2008: 572).
} 


\section{CONCLUSION}

The analysis of children's and young people's visions of the future in southern Ethiopia has revealed that they have different visions which depend on the social context and their life in agro-pastoral households and school. Children and young people living in agro-pastoral households and not having been to school or only for a number of years want to continue with an agro-pastoral lifestyle. They want to herd cattle, work in the fields and thus lead a life similar to the past and present, which underlies a cyclical time concept. Town students and older rural students, by contrast, long for jobs outside the agro-pastoral economy. They regard themselves as part of the nation-state and want to change agro-pastoral societies. Their aim is to develop both themselves and the state out of the current situation, which is proof of an underlying linear time concept.

The study has shown that there are some parallels between students' visions of the future in Africa. Students in southern Ethiopia, as well as students in Togo, Senegal, Tanzania, Ghana, Kenya, Zambia and maybe most students in the global South look for jobs in the public sector, are optimistic about their future, do not want to live as farmers or agro-pastoralists and imagine development in their life. Shortly before I left Ethiopia in June 2014, a grade 11 student summarized his thoughts of the future by saying: "When you come back in 10 years, you will not recognize me anymore. By then I will no longer walk on foot. I will go to University, find a good job, earn good money and buy a bajaj [three-wheel vehicle]. I will no longer be thin, but I will have a big belly." (Conversation in Jinka, 24/05/2014)

The student clearly described the changes that he imagines for his life in the coming years. The linear time concept forms with the growing influence of school, and maybe other factors like town life, media and religion, that could only be hinted at in this article. Like missionaries used to bring the clock and a seven-day-week to colonized countries (Munn 1992: 110), education additionally brings ideas of progress and linear time that are embedded in a developmentalist state. Through school expansion, two different understandings of future time are growing and exist within one family and between siblings, where some are going to school and some are herding cattle. The extent to which children and young people internalize the linear notion of time and development differs. Some students still regard pastoral areas as the land in which milk and honey are literally flowing. They also value that in pastoral areas they get good food without any payment, whereas in town they need money for everything. How these different visions of the future are indicators for and the cause of socio-cultural change and how the future eventually turns out, is something we will only be able to evaluate retrospectively.

\section{BIBLIOGRAPHY}

ADICK C. 2003a «Mon Avenir-Meine Zukunft. Ergebnisse aus senegalesischen und deutschen Schüleraufsätzen », Zeitschrift für internationale Bildungsforschung und Entwicklungspädagogik 26(1) : 39-46. 
ADICK C. $2003 b$ «Zukunftsvorstellungen senegalesischer Jugendlicher vor dem Hintergrund ihrer Lebenssituation im ländlichen Milieu », in I. Gogolin, J. Helmchen, H. Lutz \& G. Schmidt (eds.) Pluralismus unausweichlich? Blickwechsel zwischen vergleichender und interkultureller Pädagogik (229-244). Münster : Waxmann.

ALBER E. 2012 «Schooling or Working? How family decision processes, children's agency and state policy influence the life paths of children in northern Benin », in G. Spittler \& M. Bourdillon (eds.) African children at Work. Working and Learning in Growing Up for Life (169-194). Wien-ZürichBerlin-Münster : LIT.

Almagor U. 1978 Pastoral Partners. Affinity and Bond Partnership among the Dassanetch of SouthWest Ethiopia. Manchester : Manchester University Press.

AmborN H. 2005 «Polykephale Gesellschaften Südwest-Äthiopiens zu Zeiten der Sklavenjagden ", in S. Brüne \& H. Scholler (eds.) Auf dem Weg zum modernen Äthiopien. Festschrift für Bairu Tafla (1-28). Münster : LIT.

AMBORN H. 2004 «Fährten der Erinnerung: Die Verknüpfung von Vergangenheit und Gegenwart in Südwestäthiopien », in V. Böll, D. Nosnitsin, T. Rave, W. Smidt \& E. Sokolinskaia (eds.) Studia Aethiopica: In honour of Siegbert Uhlig on the occasion of his 65 th birthday (383-404). Wiesbaden : Harrassowitz.

AZARYA V. 1996 "Pastoralism and the state in Africa: Marginality or incorporation? », Nomadic Peoples $38: 11-36$.

BAXTER P.T.W. \& Almagor U. (eds.) 1978 Age, Generation and Time. Some Features of East African Age Organisations. London : C. Hurst \& Company.

BLOCH M. 1977 « The Past and the Present in the Present », Man. New Series 12(2) : 278-292.

BloOM P. \& KeIL F C. 2001 «Thinking Through Language », Mind \& Language 16(4) : 351-367.

BOURDILLON M.F.C 1978 « Knowing the World or Hiding It. A Response to Maurice Bloch », Man. New Series 13(4) : 591-599.

COE C. 2005 Dilemmas of culture in African schools: youth, nationalism, and the transformation of knowledge. Chicago-London : The University of Chicago Press.

DONHAM D.L. 1986 " Old Abyssinia and the new Ethiopian empire : themes in social history », in D.L. Donham \& W. James (eds.) The southern marches of imperial Ethiopia. Essays in history and social anthropology (3-48). Cambridge-New York : Cambridge University Press.

DONHAM D.L. \& JAMES W. (eds.) 1986 The southern marches of imperial Ethiopia. Essays in history and social anthropology. Cambridge, New York : Cambridge University Press.

DYER C. 2010 «Including pastoralists in Education for All », Commonwealth Education Partnerships (63-65), retrieved 23 September 2016 : [http://www.cedol.org/wp-content/uploads/2012/02/63-652010.pdf]

Epple S. 2010 The Bashada of Southern Ethiopia. A study of age, gender and social discourse. Köln : Rüdiger Köppe Verlag.

EPPLE S. 2012 «Local responses to externally induced cultural change. The introduction of formal education in Bashada (southern Ethiopia) », Paideuma 58 : 197-211.

EVANS-PRITCHARD, E.E. 1939 « Nuer Time-Reckoning », Africa. Journal of the International African Institute 12(2) : 189-216.

FULLER B. 1991 Growing-up modern. The Western state builds Third-World schools. New York London : Routledge. 
GABBert E.C. 2012 «Deciding Peace. Knowledge about War and Peace among the Arbore of Southern Ethiopia», Dissertation. Martin-Luther-Universität Halle-Wittenberg, Halle/Saale. Sozialwissenschaften und historische Kulturwissenschaften.

GeZAHEGn P. 2000 The Karo of the Lower Omo Valley. Subsistence, Social Organisation, and Relations with Neighbouring Groups. Addis Ababa : Addis Ababa University.

GÖPFERT M. \& NOLL A. 2013 Disziplin und Kreativität an ghanaischen Internatsschulen. Frankfurt am Main : Brandes Apsel.

HoNWANA A. 2014 « 'Waithood' : Youth transitions and social change », in D. Foeken, T. Dietz, L. Haan \& L. Johnson (eds.) Development and Equity. An Interdisciplinary Exploration by Ten Scholars from Africa, Asia and Latin America (28-40). Leiden : Brill.

Howe L.E.A. 1981 «The Social Determination of Knowledge. Maurice Bloch and Balinese Time », Man 16(2) : 220-234.

JEFFREY C. 2010 «Timepass : Youth, class, and time among unemployed young men in India», American Ethnologist 37(3) : 465-481.

LATOSKY S. \& ZeHLE J. 2012 "Moving Stories of the First Generation of Mursi Schoolgirls ", 18 International Conference on Ethiopian Studies, Dire Dawa, November, 1, 2012.

Lesorogol C.K. 2008 «Setting Themselves Apart : Education, Capabilities, and Sexuality among Samburu Women in Kenya », Anthropology \& Education Quarterly 81(3) : 551-577.

LYDALL J. 2010 « The paternalistic neighbor. A tale of the demise of cherished traditions », in E.C. Gabbert \& S. Thubauville (eds.) To Live with Others. Essays on Cultural Neighborhood in Southern Ethiopia (314-334). Köln : Köppe.

LYDALL J. 2005 « Hamär dialect cluster », in S. Uhlig (ed.) Encyclopaedia Aethiopica D-Ha. (983-984). Wiesbaden : Harrassowitz.

LYDALL J. 2000 « The Threat of the HIV/AIDS Epidemic in South Omo Zone, Southern Ethiopia », Northeast African Studies 7(1) : 41-62.

LYDALL J. \& STRECKER I. 1979 Baldambe Explains. The Hamar of Southern Ethiopia II. Hohenschäftlarn : Klaus Renner Verlag.

MAINS D. 2011 Hope is cut. Youth, unemployment, and the future in urban Ethiopia. Philadelphia: Temple University Press.

MASUDA K. 2003 «Banna», in S. Uhlig (ed.) Encyclopaedia Aethiopica A-C (466-467). Wiesbaden: Harrassowitz.

MunN N.D. 1992 "The Cultural Anthropology of Time. A Critical Essay», Annual Review of Anthropology 21 : 93-123.

NiEbLING M. 2010 Schooling in Hamar in the South Omo Zone. 3. Kölner Afrikawissenschaftlichen Nachwuchstagung (KANT III). 5.-7.11.2010, Köln, retrieved 23 September 2016 : [http://www.unikoeln.de/phil-fak/afrikanistik/kant/data/Niebling-KANT3.pdf]

SCHLEE G. 1990 "Altersklassen und Veränderungen der Lebenslaufalter bei den Rendille », in G. Elwert, M. Kohli \& H.K. Müller (eds.) Im Lauf der Zeit. Ethnographische Studien zur gesellschaftlichen Konstruktion von Lebensaltern (69-82). Saarbrücken : Breitenbach.

SIMPSON A. 2003 'Half London' in Zambia. Contested Identities in a Catholic Mission School. Edinburgh : Edinburgh University Press.

SPÖHR H. 2010 Zukunftsvorstellungen von Oberschülern in Mwanza, Tansania. Berlin : Weißensee. 
StAMBACH A. 2000 Lessons from Mount Kilimanjaro. Schooling, community, and gender in East Africa. New York : Routledge.STRECKER I. 2013 Berimba's Resistance. The Life and Times of a Great Hamar Spokesman. As told by his son Aike Berinas. Wien-Berlin-Münster : LIT.

STRECKER I. 2005. «Hamär Ethnography », in S. Uhlig (ed.) Encyclopaedia Aethiopica. D-Ha. (984986). Wiesbaden : Harrassowitz.

STRECKER I. 1995 "Ethno-History and Its Relevance for Ethiopian Studies », Journal of Ethiopian Studies 28(2) : 39-49.

STRECKER I. 1976 «Hamer Speech Situations », in L.M. Bender (ed.) The Non-Semitic Languages of Ethiopia (583-596). East Lansing-MI : African Studies Center, Michigan State University.

ThubauviLle S. 2012 «Brides behind bars. Maale women as captives between tradition and development », Paideuma 58 : 213-228.

TORNAY S. 1981 « The Nyangatom. An outline of their ecology and social organization », In M.L. Bender (ed.) People and Cultures of the Ethio-Sudan Borderlands (137-177). East Lansing: African Studies Center.

TURTON D. 1978 «Territorial Organisation and Age among the Mursi », in P.T.W. Baxter \& U. Almagor (ed.) Age, Generation and Time. Some Features of East African Age Organisations (95-130). London : C. Hurst \& Company.

WALLMAN S. 1992 "Introduction: Contemporary Futures", in S. Wallman (ed.) Contemporary Futures. Perspectives from Social Anthropology (1-20). London : Routledge.

WHORF B.L. 1956 Language, Thought, and Reality. Cambridge, MA : MIT Press.

WiSEMAN B. 2001 «Claude Lévi-Strauss, Chiasmus and the Ethnographic Journey », University of Edinburgh, Arachnofiles (2), retrieved 23 September 2016: [http://www.ed.ac.uk/files/imports/fileManager/Claude\%20Levi\%20Strauss\%20Chiasmus\%20an d\%20the\%20Ethnographic\%20Journey.pdf]

ZeleKe B. \& ZeleKe S. 2012 «Evaluation of Save the Children Norway's Promotion of Basic Education Project in Hamer Woreda, South Omo Zone of SNNPR. Final Report », Addis Ababa : Fountain Management Consultancy, retrieved 23 September 2016 : [https://ethiopia.savethechildren.net/sites/ethiopia.savethechildren.net/files/library/EVALREPETH-2012-13.pdf]

ZitelmanN T. 1990 «Verzeitlichung und Lebenslauf. Die Alters- und Generationsklassenordnung (Gada) der Borana-Oromo », in G. Elwert, M. Kohli \& H.K. Müller (eds.) Im Lauf der Zeit. Ethnographische Studien zur gesellschaftlichen Konstruktion von Lebensaltern (50-68). Saarbrücken : Breitenbach. 